\title{
THE EFFECT OF PERPHENAZINE ON EPINEPHRINE-INDUCED CARDIAC ARRHYTHMIAS IN DOGS. II, ANAESTHESIA WITH CYCLOPROPANE, CHLOROFORM, AND TRICHLORETHYLENE ${ }^{1}$
}

\author{
Allen B. Dobkin, m d , ${ }^{2}$ Hakry Donaldoson, m d, 2 and Noel Purkin, B.A. ${ }^{3}$
}

IN ADDITION to the clinical efficacy of perphenazine (Trilafon ${ }^{8}$ ) in alleviating symptoms of anxiety and other manifestations of emotional stress (1-4), this drug exerts a significant depressive effect on epmephrine-provoked myocardial irritability if it is administered before general anaesthesia with Fluothane and the azeotropic mixture of Fluothane and diethyl ether in dogs (5).

A dose level of perphenazine $(0.25 \mathrm{mg} / \mathrm{kg}$.) was selected for studying the effect on myocardıal irritability that would not alter the pulse rate, blood pressure, or respiratory pattern in the dogs, and, if translated into the dose that would be required for clinical anaesthesia, would not be excessive in man, or exceed the effective therapeutic range for moderate sedation $(01 \mathrm{mg} . / \mathrm{kg}$.).

Further studies in dogs were carred out to determine whether the protection afforded by perphenazine against l'epinephrine-provoked cardiac arrhythmias would apply also to anaesthesia with cyclopropane ( 25 per cent), chloroform ( 05 per cent), and trichlorethylene ( 1 per cent), since these agents are known to provoke spontaneous cardiac arrhythmias when inhaled during spontaneous respiration, and cause serious ventricular arrhythmias if l'epinphrıne is administered during anaesthesia with these hydrocarbons $(6,7,8,9)$

\section{METHOD}

Thurty-six acute experiments carried out on twenty-nine mongrel dogs are reported These animals varned in werght from 55 to $17 \mathrm{~kg}$. (mean, $85 \mathrm{~kg}$.). The same technical procedure was followed as was reported in the preceding experıments (5).

The concentration of each anaesthetic agent employed was specially selected, after preliminary trials, in order to produce a stable plane of surgical anaesthesia within a few minutes when the dog's tidal volume and airway pressure were preset on a respirator, and would not cause significant cardiovascular depression or the development of electrocardlographic evidence of spontaneous myocardial irritability while pulmonary ventilation was adequate

Cyclopropane-oxygen (25-75 per cent) was administered through a semi-closed circle system with fresh baralyme in the circuit, employing gas flows of at least $200 \mathrm{ml}$. cyclopropane and $600 \mathrm{ml}$. oxygen. Chloroform 0.5 per cent and trichlorethylene 1 per cent were administered from a calıbrated Fluotec vaporizer with

1Supported in part by a grant-in-and from Schering Corporation, Montreal, Canada.

2From the Department of Anaesthesia, University of Saskatchewan College of Medicine and the Anaesthesia Laboratory, Medical Research Buldıng, Saskatoon, Canada

${ }^{3}$ Medical Student Research Assistant from the Unversity of Saskatchewan College of Medicıne 
the vaporization setting at 05 and 3 per cent respectively (10). At least $7 \mathrm{~L}$. gas $/ \mathrm{min}$. flowed through the vaporizer contmuously $\left(\mathrm{N}_{2} \mathrm{O}, 5, \mathrm{~L} .+\mathrm{O}_{2}, 2 \mathrm{~L}\right.$. $)$. The concentration, dose and rate of injection of epinephrine $(0.02 \mathrm{mg} . / \mathrm{ml} / \mathrm{kg}$. body weight/sec.) was the same as used previously (5), and was also specially selected in order that the electrocardıogram of the dog would probably show ventricular extrasystoles, ventricular tachycardia, multifocal ventricular extrasystoles, or ventricular fibrillation after $20 \mathrm{~m}$ n of each of the anaesthetic agents.

\section{Results}

\section{Cyclopropane 25 per cent and Oxygen 75 per cent}

No significant spontaneous arrhythmias appeared during the 20 minutes of anaesthesia in twelve acute experiments on nine dogs The only alteration that was observed on the electrocardiogram was a slight sinus arrhythmia and a progressive

\section{TABLE I}

Effect of Perphenazine on Epinephrine-induced Cardiac Arrhythmias during 25 per Cent Cyclopropane-75 PLR Cent Op ANaesthesia in Dogs

\begin{tabular}{|c|c|c|c|c|c|}
\hline Dog & $\begin{array}{c}\text { Welght } \\
(\mathrm{kg})\end{array}$ & $\begin{array}{l}\text { Dose of } \\
\text { epinephrme } \\
\text { (m̄g) }\end{array}$ & $\begin{array}{c}\text { Dose of } \\
\text { perphenazine } \\
\text { (mg) }\end{array}$ & $\begin{array}{c}\text { Onset of } \\
\text { arrhythmia } \\
\text { after injection } \\
\text { (secs) }\end{array}$ & $\begin{array}{l}\text { Duration of } \\
\text { arrhythmia } \\
\text { (secs) }\end{array}$ \\
\hline 1 & 110 & 022 & 28 & 10 & $7\left(F_{1 g} 1\right)$ \\
\hline 2 & 62 & 012 & 15 & 3 & 24 \\
\hline 3 & 78 & 016 & 0 & -2 & $530-V F$ \\
\hline 4 & 90 & 018 & 0 & -4 & 194-VF \\
\hline 5 & 80 & $\begin{array}{lll}0 & 16\end{array}$ & $\begin{array}{lll}2 & 0\end{array}$ & -1 & 6 \\
\hline 6 & 60 & 012 & 15 & 11 & 13 \\
\hline 1 & 110 & 022 & 0 & -3 & $224-V F$ \\
\hline 3 & 78 & 016 & 20 & 8 & 9 \\
\hline 4 & 90 & 018 & 23 & \multicolumn{2}{|c|}{ Tachycardia-Bradycardıa } \\
\hline 7 & 160 & 032 & 40 & VF-Death* & \\
\hline 8 & 170 & 034 & +2 & 12 & $36\left(F_{1 g} 2\right)$ \\
\hline 9 & 132 & 026 & 33 & 0 & $0 \dagger$ \\
\hline
\end{tabular}

*Mechanical diffículty durıng anaesthesıa

†Bradycardia and hypotension after experiment, death in 3 hrs

slowing of the heart rate In seven of the nine dogs, the heart rate slowed to less than half after 20 minutes of cyclopropane, as compared to that in the control period (Fig. 1A, B). In the other two dogs there was little or no change in the heart rate (Fig 2A and B). In six experiments, femoral artery pressures were recorded, but there was no significant alteration before the injection of l'epinephrine.

In the three animals which did not receive perphenazine there was a period of at least 3 minutes in which paroxysmal auricular tachycardia, ventricular tachycardia, multifocal ventricular extrasystoles, and ventricular fibrillation appeared on the electrocardiogram after the injection of l'epinephrine The blood pressure rose immediately after injection of l'epinephrine and then fell rapidly to a very low level. 




Ficuhe 1 Observe brielycardia after 20 mun of 25 per cent cyclopropune, and short run of proyymal ventrlcular tachycrodin after 022 pyg 1 eprnephrne in $11 \mathrm{~kg}$ dog premedicited with $28 \mathrm{mg}$ perphenuzine $A$, control betore cyclopropane, slight sibus arrhythond at $188 / \mathrm{mmn}$, B aftur 20 mun of 25 per cent cyclopropane, slught sinus arrhythmiı at $82 /$ num $C_{3}$ end of injectuon of 1 upincphrinc, rile increasing $\mathrm{D} 9 \mathrm{sec}$ after $\mathrm{C}$, puroysmal ventrucul ir tichycarda it $180 / \mathrm{mun}, \mathrm{E}, 14 \mathrm{sec}$ after $C$, $P$ wancs rappear, $F 30$ sec after $C$, shroht sumb arrintlum it $100 / \mathrm{mm}$

In the other nine expenments in which peiphenazine premedication was adminstered, the following obscrvations were recorded One dog (no 4) had a bref period of panoxysmal aurcula tachycardia, followed by a short run of slow ventriculat lhythm, then normal compleves appeared at the rate seen before the mpection of epineplirine in another expenment (no 7) there was some mechanical difficulty with the antomatic respirator which was ventalang the dog 7 his caused signs of obstiuctive breathing inteimittently during the 20 minutes cuntrol penod When the l'epinephrine was injected, ventricular tachycardia developed immediately and changed abruptly in a few seconds to ventricular fibrillation Another dog (no 9) had no arrhythmias during the experiment, but developed a severe biadycar dia and hypotension about 7 munutes after the l'epinephrme mjection and discontinuation of cyclopropane This rate was iegular at between $26-30 /$ minutes for over $2 / 2 \mathrm{hrs}$, with gi udual reduction of the voltage During this time only oxygen was administered with the respirator Spontaneous breathing did not retuin and the blood pressue became too low to record after 3 hrs When the respuator was disconnected the anmal expured promptly This death may have been due to "cyclopropane shock" or to the effects of a relatuve 




Frgure 2 Observe that there was no iltertion in the heart rate after $20 \mathrm{mmn}$ of 25 per cent cyelopropane, and short run of ventricular cstrisystoles ifter $034 \mathrm{mg}$ l'epineplirine $A$, control before cuclopropane (after perphenazune), slight smus irrhythmu at $144 / \mathrm{min}, \mathrm{B}$, after $20 \mathrm{~min}$ of 25 per cent cuclopropane, unchanged, $\mathrm{C}$, end of injection of 1 epinephrme, heart rate incresseci to $230 / \mathrm{mm} \quad \mathrm{D} 12 \mathrm{scc}$ after $\mathrm{C}$, multifocal ventricul ir extr isrstoles $\mathrm{E} 30$ sec ifter $C$, ventricular atrisystoles followed by norm'l rhythm, F 60 sec ifter $C$ normil rhythm rate $150 / m m$

overdose of cyclopropane A response like this was reported by Morrs and associates in a similar experiment with chloroform (9)

The other six dogs that recerved perphenazme had very bref i uns of paroxysmal supraventricular tachycardia with a few ventricular extrasystoles (see Figs 1 and $2, \mathrm{C}$ to $\mathrm{F}$ )

\section{Chloroform 05 per cent with Nutrous Oxule 70 per cent and Oxt/gen 30 per cent}

These experiments were done initally with 1 per cent chloroform, because it was reported that dogs were very much more resistant to chloroform-epmephrine syncope than to that with cyclopropane (6) However, this concentration caused hypotension By tral it was found subsequently that 05 per cent chloroform and 70 per cent nitrous oxide with controlled respiration was sufficient to produce a preparation that would respond to epinephrine with ventricular arrhythmias, but would not cause marked alteration of the blood pressure during the prelammary 20 minutes of anaesthesia 
IABLE II

Ltflet or Perphinazinl on Epindphrini-jnducld Cardiac Arrhythmias dliking 05 per CENT ChlokOForM $+\mathrm{N}_{2} \mathrm{O}_{9}(52)$ ANAESTHLSIA in DOGS

\begin{tabular}{|c|c|c|c|c|c|}
\hline Dog & $\begin{array}{c}\text { Weight } \\
(\mathrm{kg})\end{array}$ & $\begin{array}{l}\text { Dose of } \\
\text { epunephrime } \\
\text { (mg) }\end{array}$ & $\begin{array}{l}\text { Dose of } \\
\text { perphenazine } \\
\quad \text { (mg) }\end{array}$ & $\begin{array}{l}\text { Onset of } \\
\text { asthythimia } \\
\text { alter injection } \\
\text { (secs) }\end{array}$ & $\begin{array}{l}\text { Duration of } \\
\text { arrhythmia } \\
\text { (secs) }\end{array}$ \\
\hline 1 & 110 & 022 & 28 & 3 & $7 \pm\left(\operatorname{see} F_{1 g} 3\right)$ \\
\hline 2 & 90 & 018 & 23 & 9 & 56 \\
\hline 3 & 60 & 014 & 0 & 4 & 144 \\
\hline 4 & 59 & () 12 & 0 & 3 & 93 \\
\hline 5 & 9 1 & 018 & 23 & \multicolumn{2}{|c|}{ Tachycarda only } \\
\hline 6 & 50 & 010 & 13 & 5 & 16 \\
\hline 1 & 110 & 022 & 0 & -1 & VF-Death (see Fig 4 ) \\
\hline $\overrightarrow{7}$ & 60 & 012 & 0 & 0 & 264 \\
\hline 8 & 104 & 021 & 25 & 2 & 16 \\
\hline l) & 10 & $0 \mathrm{18}$ & 23 & 3 & 18 \\
\hline 10 & 80 & 016 & $\overline{0}$ & 2 & 156 \\
\hline 5 & 19 & 018 & 0 & -2 & 290 \\
\hline
\end{tabular}

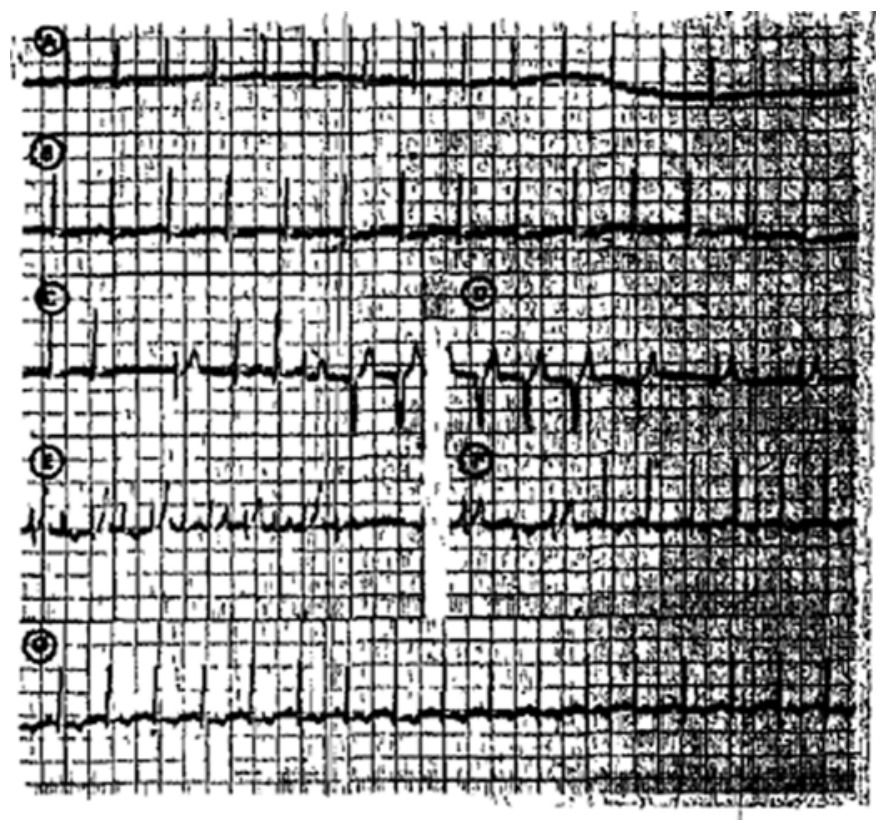

FuGule 3 Observe slight bradycardia after $20 \mathrm{mmn}$ of 05 per cent chloroform and ventricular arrhythmias ufter $022 \mathrm{mg}$ epmiphrme $1 \mathrm{~m} 11 \mathrm{~kg}$ dog premedicated with 28 perphenasine $A$, control before chloroform, rate $136 / \mathrm{mm}, \mathrm{B}$, after $20 \mathrm{~min} 05$ per cent chloroform, rate $120 / \mathrm{min}, \mathrm{C}$, end of injection of l'epmeplurinc, onset of A-V dissocintion, D, 30 sec after C, A-V dissocintion, $E, 45$ sec after $C$, multifocal ventrıcular extrasystoles, $F, 73$ sec after $C$, normal sinus rhythm renppears, $G, 90$ sec after $C$, normal sinus rhythm, rate $140 / \mathrm{mm}$ 
No spontaneous cardiac arrhythmias appeared in the twelve acute experments in the ten dogs, exther during induction of anaesthesia or during the 20 munutes prior to admunstration of l'epmcphrme Each of the dogs had a slught reduction in the heart rate whthn about 5 munutes after beginning the chloroform The reduction of heart rate was not progressive during the 20 munutes of anaesthesia (see Figs $3 \mathrm{~A}-\mathrm{B}$, and $4 \mathrm{~A}-\mathrm{B}$ )

in the six experments in which the anma' received perphenazme, a brief run of increased heart rate, followed by atroventricular rhythm, nodal and ventricular extrasystoles and slow ventroular rhythm were observed In only one of these anmals did the arrhvthmias persist for mose thin I monute (see Fig 3)

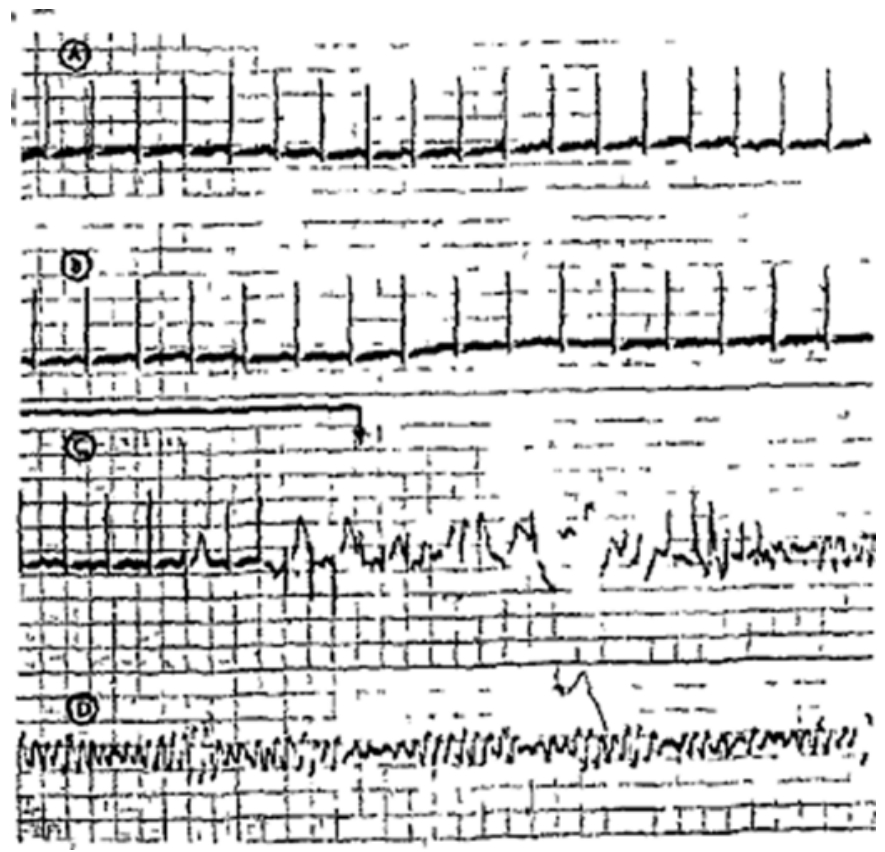

Ficure 4 Observe slight brodycardı aftur $20 \mathrm{~mm}$ of 05 per cent chloroform ind telescoping of progression of arrhythmas to ventricular fibrilhtion when epmephrme $(022 \mathrm{mg})$ was $x$ minnstered in the unpremedicated dog (s tme imminl is in Fig 3)

In the other six experiments, in which no perphenazine was given, the anımals developed bursts of supraventicular tachycardia, ventricular tachycarda, and nultifocal ventricular extrasystoles In five of these experiments the arrhythmas persisted for at least 90 seconds and showed the appearance of a "prefibrillation phase "One anmal abruptly developed ventricular fibrillation 4 seconds after the injection of l'epunephrine (see Fig 4)

Trichlorethylene I per cent with Nitrous Oxide 70 per cent and Oxygen 30 per cent

No signuficant spontaneous arrhythmas appeared during the 20 munutes of anaesthesia in twelve acute experiments on ten dogs There was also no significant alteration $\mathrm{m}$ the heart rate or blood pressure In the six experiments in which 
TABLE III

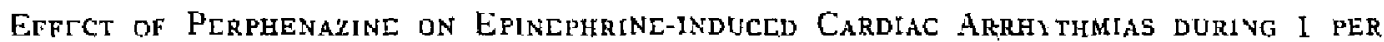
Cent Trichlorethylenc $+\mathrm{N}_{2} \mathrm{O} \mathrm{O}_{-}(52)$ Anaesthlesia in Dogs

\begin{tabular}{|c|c|c|c|c|c|}
\hline Dog & $\begin{array}{l}\text { Weight } \\
\text { (kg) }\end{array}$ & $\begin{array}{l}\text { Dose of } \\
\text { epinephrute } \\
\text { (mg ) }\end{array}$ & $\begin{array}{l}\text { Dose of } \\
\text { perphenazine } \\
\text { (mg) }\end{array}$ & $\begin{array}{l}\text { Onset of } \\
\text { arrhythmia } \\
\text { after injection } \\
\text { (secs) }\end{array}$ & $\begin{array}{l}\text { Duration of } \\
\text { arthy thmial } \\
\text { (secs) }\end{array}$ \\
\hline 1 & 80 & 017 & 22 & 6 & 18 \\
\hline 2 & 70 & 014 & 18 & $i$ & 27 \\
\hline 3 & 60 & 012 & 0 & 3 & 163 \\
\hline$t$ & 55 & 011 & 0 & 7 & 221 \\
\hline 5 & 83 & $0 \quad 16$ & 20 & \multicolumn{2}{|c|}{ Tachycardia only } \\
\hline 6 & 68 & 014 & 18 & $1 \pm$ & \multirow{3}{*}{$\begin{array}{c}55 \\
\text { VT \& VF-13 num } \\
\text { (1ntermittently) } \\
\text { VF-Death }\end{array}$} \\
\hline$i$ & 80 & 016 & 0 & 4 & \\
\hline 2 & 70 & $0 \quad 14$ & 0 & 3 & \\
\hline 8 & 64 & 013 & 16 & 5 & 66 \\
\hline 9 & 112 & 022 & 28 & 8 & $124\left(\mathrm{~F}_{1 \mathrm{~g}} \quad 5\right)$ \\
\hline 5 & 83 & 016 & 0 & 6 & $1 F-$ Deal h \\
\hline 10 & 82 & 016 & 0 & $\xi$ & $182\left(F_{\lg } 6\right)$ \\
\hline
\end{tabular}

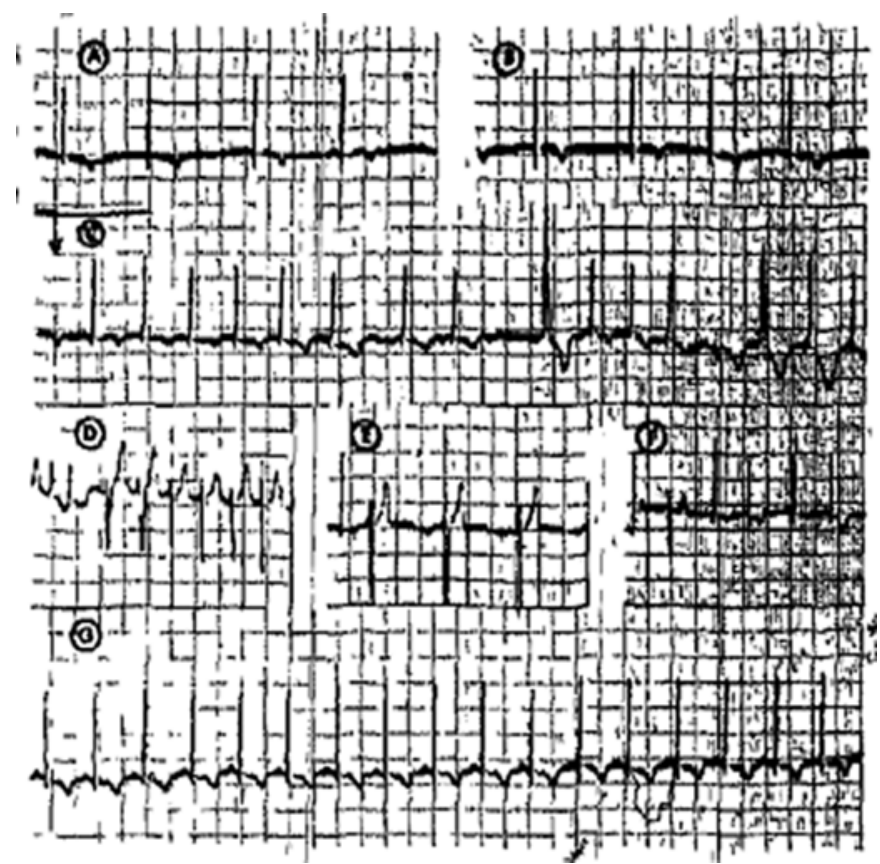

Fycuns 5 Observe yentricular arrhvthmias after lepinephrine $A$, control before trichlorethylene, sinus arrhythman (9) 82: B, after 20 mn 1 per cent trichlorethylene, sinus arrhythma (a) 84, C, end of injection of l'epineplinne (022 mg), immediate morense in heart tate, and appentance of ventricular extrasystoles, D, E, F 30,40 and 1.20 sec after $C$, ventricular extrasystoles, $G, 130$ sec after $C$, wands rhythm

perphenazıne premedication was given, there were no arrhythmias in one, and up to 2 minutes of intermittent ventricular arrhythmias in the other five after the injection of epmephrme (see Fig 5) 
In the other six experments, the animals did not receive perphenazine Three of them developed ventricular fibrillation-two of these died quickly, while the other alternated between ventricular tachycardia, multfocal ventricular extrasystoles, and ventricular fibriliation for $1 \$$ minutes The other three had long runs of ventracular arrhythmias that appeare at at tmes to change to fibrillation, but they each reverted to a slow ventrucular rhythm, whuch gradually accelerated until a near normal rate and configuration reappeared (see Fig 6)



Figuhe 6 Observe prefibrill tion phase of ventr. Eular arrhythmes appe iring shortly ifter injection of epinephrine $A$, control before trichlorethylene, rat. $115 / \mathrm{m} n, \mathrm{~B}$, after $20 \mathrm{~mm} 1$ per conl trichlorethylcn rate $108 / \mathrm{mm}, \mathrm{C}, 3$ sec ifter injection of l cpinc. phrine (016 mg)-bract uppe rarice of ventrucular fibrillation, then multifos al icntricul is extrasystoles D, 166 sec after C, slow ventruculas shy thm E 180 sec: after $C$, return of sunus rhythm $\Gamma 240$ sec ifter C, sinus rhvthm rate $90 /$ mun

\section{Discussion}

The demonstration of a protective action aganst experimentally provoked cardiac arrhythmas by epmephrme has been carned out with many drugs, employing a variety of techniques (11) These have led to wide varatons in experimental observations and in opmions expressed regarding the conclusions that may be drawn

The procedure employed in the present stucly was selected in order to elimmate as many variable factors as possible $A$ small amount of thiopental was given intrayenously in order to prepare the animal quickly, and to avord a stormy induction of anaesthesia Respiratory tidal volume and arrway pressure 
were regulated in order to assure that pulmonary ventilation would be adequate at all tumes, and that the desired concentration of the primary anaesthetic would be delivered to the lungs and would establısh a surgical plane of anaesthesia in a few munutes The liquid anaesthetces were delivered from a callbrated Fluotec vaporizer, which is temperature compensated, in order that varuation in the concentration of these agents would be avoided even if the anmal should take a deep breath, and to elmmate the possibtluty of sudden wide changes in the depth of anaesthesia The specific concentrations of the anaesthetics which were selected were chosen because they did not cause marked hypotension (or hypertension) duing the initral 20 mmutes of anaesthesia which were required to prepare the anmal for the acute experment

A fixed concentiation and rate of injection were decided upon for the intravenous admmistration of l'epmephrme, with total dose dependent upon body weight This method was used iather than adminsterung l'epmephrme untrl a particulur cardiac response might be observed because the latter technique elimmates the factors of rate and dose and renders comparison of response with different anaesthelic agents more difficult

A light level of chloroform anaesthesia was chosen because deep chloroform anzesthesia depresses all functions of the heart, lowers the blood pressure. and peilhaps rechuces the susceptibility to the peculiarly lethal effect of licpmephrine In fact, under deep chloroform, l'epmephrne may be an effective restorative of a rapidly succumbing circulation $(12,13)$ This is probably true also with Fluothane and the azeotropic muture of Fluothane and drethyl ether (5) On the other hand, with atificial iespiration, a high concentiation of cyclopropane was used because this abolshes or minimizes the madence of spontaneous anhythmins, but also increases the susceptibility to ventricular arrhythmias provoked by l'epmephrme (14)

It was stated that, clmically, spontaneous cardiac arrhythmas have been noticed frequently during trichlorethylene anaesthesia either by palpation of the pulse or by the electiocardiograph $(7,8)$ In these early reports, the concentration of the mhaled vapour probably exceeded 2 per cent, or the arrhythmis were transient and appcared only duing induction of anaesthesia (15) Serious venticular arhythmias may occu spontaneously only under deep anaesthesia with bichlorethylene, when rapid shallow bieathing occurs, and causes hypoxclemia (16) In the animal studies reported here, no spontaneous arrhythmias were observed during the mitial 20 muntes of anaesthesia in distmction to what has been observed by others $(8,9)$ This may be explamed by the fact that induction of anaesthesid was always smooth, and pulmonary ventlabon was supported sufficently to maintain normal respuation When lepmephrine was injected, however, these anımals appeared to be far more susceptible to ventricular fibrillation than with any of the other agents studied

Perphenazine was observed to exert a protective action on the heart agamst ventricular arrhythmias, without apparent potentiation of the effect of the primary anaesthetics, and without altering the pulse rate or the blood pressure of the dogs, although the arrhythmias were not elmmated 
The complete elimination of cardiac arrhythmias with perphenazine may be possible by greatly increasing the dose or by altering the amount of anaesthetics administered. Hawever, the first manoeuvre would cause potentiation of the anaesthetics, and mduce undesirable lowering of the blood pressure and possibly myocardial depression, while the second manoeuvre would alter grossly the optimum experimental procedure, and detract from the validity of any conclusions that may be drawn from the observations.

It appeared from these studies that perphenazıne was more potent than chlorpromazine in reducing the duration and severity of cardiac arrhythmias provoked by l'epinephrine, and had no significant effect on the pressor response to l'epinephrine at the dose level tested $(17,18,19)$.

\section{Summary and Conclusions}

The effect of 25 per cent cyclopropane, 0.5 per cent chloroform with 70 per cent nitrous oxide and 1 per cent trichlorethylene with 70 per cent nitrous oxide on the heart rate was observed during thirty-six acute experiments in dogs in which pulmonary ventilation was regulated, and the concentrations of the inhaled anaesthetics were accurately controlled. There was marked slowing of the heart rate with cyclopropane, slight slowing with chloroform, and little or no change with trichlorethylene. There was no significant difference in the heart rate in the animals that were premedicated with perphenazine $0.25 \mathrm{mg} / \mathrm{kg}$, as compared to the unpremedicated animals.

Sensitization to epinephrine-provoked cardiac arrhythmias by a standard concentration and rate of injection $(002 \mathrm{mg} / \mathrm{ml} / \mathrm{sec}$.) were observed, when the total dose was regulated according to the animals' werght It was found that ventricular fibrillation was less likely to occur when epinephrine was injected during anaesthesia with 0.5 per cent chloroform than with 25 per cent cyclopropane, or with 1 per cent trichlorethylene. In a simlar study with Fluothane and the azeotropic mixture of Fluothane and diethyl ether, the cardiac response to epinephrine with 0.5 per cent Fluothane was similar to that with 25 per cent cyclopropane, and the 1 per cent of the azeotropic mixture was similar to that with 0.5 per cent chloroform.

Premedication with perphenazine $(0.25 \mathrm{mg} . / \mathrm{kg}$.) caused a significant reduction in the severity and duration of the cardiac arrhythmias provoked by epinephrine if pulmonary ventilation was adequate throughout the experiment, but did not cause reversal of the pressor response. It was suggested that the elimination of epinephrine-provoked cardiac arrhythmias by perphenazine would require such alteration in the depth of anaesthesia or dose of perphenazine as would reduce the validity of the results of these experiments for practical application.

\section{ACKNOWLEDGMENTS}

Trilafon ${ }^{\circledR}$ was supplied by Dr. W. MacDonald of Schering Corp., Montreal. Mr. S Meakın of the Medical Research Laboratory, University of Saskatchewan, provided very helpful technical assistance throughout these studies. 


\section{RÉSUMÉ}

Nous avons étudté l'effet sur le rythme cardiaque de 25 pour cent le cyclopropane, de 0.5 pour cent de chloroforme avec 70 pour cent de protoxic e d'azote et de 1 pour cent de trichlorethylène avec 70 pour cent de protoxide. d'azote chez trente-six chiens dont la ventilation pulmonaire était maintenue et dont les concentrations d'agent's anesthésiques inhalés étaient précisement contrôlées. Nous avons observé un ralentissement marqué du cœur avec le cyclopropane, un léger ralentissement avec le chloroforme et peu ou pas de changement avec le trıchlorethylène Chez les anımaux prémédıqués avec de la perphénazine 0.25 mg./kg., nous n'avons pas observé de différence dans le rythme cardiaque comparativement aux anımaux non prémédiqués.

Nous avons observé une sensibilisation à provoquer des arythmies cardiaques par l'épınéphrine à une concentratıon et à une vitesse d'injection standard $(0.02$ $\mathrm{mg} . / \mathrm{ml}$. sec.) lorsque la dose totale était calculée d'après le poids des animaux. Nous avons observé que la fibrillation ventriculaire était moins exposée à survenir lorsque l'épınéphrine était injectée durant l'anesthésie avec 0.5 jour cent de chloroforme que durant l'anesthésie-avec 25 pour cent de cyclopropane ou avec 1 pour cent de trichlorethylène. A la sute d'une étude semblable avec le Fluothane et le mélange azéotrope Fluothane et éther diéthylique, nous avons noté que la réponse cardiaque à l'épinéphrine avec 05 pour cent de Fluothane était semblable à celle observée avec 25 pour cent de cyclopropane et que celle de 1 pour cent du mélange azéotrope était semblable à celle de 0.5 pour cent de chloroforme.

La prémédication avec de la perphénazine $(025 \mathrm{mg} . / \mathrm{kg}$.) a entraîné une réduction importante de la sévérité et de la durée des arythmies cardiaques provoquées par l'épinéphrine à la condition que la ventilation pulmonaire soit adéquate durant toute l'expérience, mais elle n'a pas inversé l'effet presseur. Il nous a semblé que l'élimination par la perphénazine des arythmies ventriculaires provoquées par l'épinéphrine nécessiterait une telle profondeur d'anesthésie ou des doses telles de perphénazine que la valeur pratique des résultats de ces expériences serait bien diminuée.

\section{REFERENCES}

1 AxD, F J The Treatment of Anxiety, Agitation and Excitement in the Aged A Prelimmary Report on Trilafon I Am Genat Soc 592 (1957)

2 Cahn, C H, \& Lehmanv, H E. Perphenazine Observations on the Clinical Effects of a New Tranquillzing Agent in Psychotic Conditıons Canad Psychiat A I. 2104 (1957).

3 Ayd, F I Treatment of Ambulatory and Hospitalized Psychatric Patients wnth Trilafon. Dis Nerv Syst 18 394 (1957)

4 Harer, W B Tranquillizers in Obstetrics and Gynecology Studies with Trilafon Obst \& Gynec $11273(1958)$

5 ровкіn, A. B \& Punkin, N The Effect of Perphenazıne on Epinephrine-induced Cardiac Arrhythmias in Dogs I, Anaesthesia with Fluothane and the Fluothane-Ether Azeotrope. Canad. Anaesth. Soc J. 6: 243-250 (1959). 
6 Meek, W J. Cardiac Automaticity and Response to Blood Pressure Raising Agents durmg Inhalation Anaesthesia Physiol Rev 21 324 (194:1)

7 Hewer, C L \& Hadfield, C F Trichlorethylene as Inhalation Anaesthetic Brit. Med J. 1: $924(1941)$

8. Waters, R M, ORth, O.S \& Gillespie, N A Trichlorethylene Anaesthesia and Cardiac Rhythm Anestheswology 4. 1 ( 1943).

9 Monris, L E, Noltensmeyer, M H \& Whute, J M., Jr. Epinephnne-mduced Cardiac Irregularities in the Dog during Anesthesia with Trichlorethylene, Cyclopropane, Ethyl Chloride and Chloroform Anesthesiology 14 153 i 1953).

10 Keasling, H H \& Prtringer, C B. Fluotec Performance Anesthesiology 19682 (1958)

11. Dawes, G S Expermmental Cardiac Arrhythmias and Qumidıne-like Drugs Pharmacol. Rev 443 (1952)

12 Levr, A G The Genesis of Ventricular Extrasystoles under Chloroform with Special Reference to Consecutive Ventricular Fibrillation Heart 5299 (1914)

13 Meex, W J, Hathaway, H R \& Orti, O S The Ellects of Ether, Chloroform and Cyclopropane on Cardiac Automaticity J. Pharmacol \& Exper Therap 61240 (1937)

14, Lee, W V, Orth, O S, Wangeman, C. P \& Meek, W. J. The Mechanism of Production of Spontaneous Cardiac Irregularities with High Concentrations of Cyclopropane Anesthesiology 4487 (1943)

15 Ostrere, G. The Role of Trichlorethylene in General Anaesthesia Brit Med J 1 195 (1948)

16 Barnes, C G, \& Ives, J Electrocardıographic Changes during Trilene Anaesthesia. Proc. Roy Soc. Med 37528 (1944)

17 Melvilie, K I Observations on Adrenergic-blocking and Antifibrillatory Action of Chlorpromazine Fed Proc 13386 (1954)

18. Dobkin, A B, Gilbert, R G B, \& Melville, K I Chlorpromazine Revew and Investigation as a Premedicant in Anesthesia Anesthesiology 17135 (1956)

19 Winbury, M M, Hausler, L M, Wolf, J K, Klein, M J, \& Govier, W M Suppression of Cyclopropane-Epinephrine Arrhythmas in Dogs by Four Phenothrazine Derivatives Anesthesiology 19743 (1958) 